Arab World English Journal (AWEJ) Volume 12. Number4 December 2021

DOI: https://dx.doi.org/10.24093/awej/vol12no4.32

\title{
English as a Second Language and English as a Foreign Language Preservice Teacher Cognitions: Research Insights from around the World (2005-2021)
}

\author{
Mustapha Chmarkh \\ Department of Teaching and Learning \\ College of Education and Human Ecology, The Ohio State University \\ Columbus, OH. USA \\ Email: chmarkh.1@buckeyemail.osu.edu
}

Received: 6/22/2021

Accepted: 11/19/2021

Published:12/15/2021

Abstract. This review examined English as a Second Language (ESL) and English as a Foreign Language (EFL) preservice teacher cognition studies spanning a 17-year period (2005 to 2021). The main objective was to explore the nature and development of preservice ESL and EFL teacher cognitions as they relate to their teacher-education coursework and teaching practice. Findings indicate that preservice ESL/EFL teacher cognitions are complex, multifaceted, recursive, and frequently related to their experiences as language learners. Although studies included in this review were conducted in different international contexts, the findings were consistent: there is a need for supportive and comprehensive preservice-teacher preparation that accounts for three factors. (1) Valuing preservice teachers' beliefs as language learners, (2) facilitating preservice teachers' negotiation of newer beliefs resulting from teacher education coursework, and (3) preparing them to negotiate tensions in their interactions with their mentors in field placements. This paper concludes by discussing pedagogical implications for teacher education programs.

Keywords: cognitions, English as a Foreign Language, English as a Second Language, perceptions, preservice teachers, teacher education

Cite as: Chmarkh, M. (2021). English as a Second Language and English as a Foreign Language Preservice Teacher Cognitions: Research Insights from around the World (2005-2021) Arab World English Journal, 12 (4) 487-502.

DOI: https://dx.doi.org/10.24093/awej/vol12no4.32 


\section{Introduction}

The Oxford Dictionary (2019) defines cognition as "The mental action or process of acquiring knowledge and understanding through thought, experience, and the senses." At first glance, we can already anticipate the heavily mental and mostly abstract components of cognition. Being a mental action through which a person acquires knowledge, cognition can be seen as a dynamic process. Of great significance here is the fact that this definition refers to cognition as a process of understanding that combines abstract components (thoughts) with concrete elements (experiences and senses). Not surprisingly, research on preservice teacher cognition has underscored the complexity of examining teacher cognition since the latter involves conscious and unconscious beliefs that influence teaching practice without being always concretely articulated by teachers. For instance, Burns, Freeman, and Edwards (2015) described the cognitions of language teachers as: "situated, dynamic, mediated, and inherently complex" ( $p$. 597) while Borg (2003) underscored the complexity of examining teacher cognitions: "teachers are active, thinking decision-makers who make instructional choices by drawing on complex, practically-oriented, personalized, and context-sensitive networks of knowledge, thoughts, and beliefs" (p. 81). By saying that, Borg refers to the networks of beliefs that teachers draw upon as personalized and context sensitive. Such distinction adds an additional layer of complexity to the examination of teacher cognition. That is, such examination should consider teachers' individual differences and the unique teaching context(s) where they evolve. In this view, preservice teacher cognition research has been interested in exploring how preservice teachers' beliefs develop as a result of engaging in coursework, reflection, and practicum. In addition, this strand of research examines how cognitions facilitate or mitigate preservice teachers' learning experiences and teaching practice.

This paper aimed at reviewing 23 empirical studies on ESL and EFL preservice teacher cognitions from around the world. The selection of empirical studies followed specific inclusion criteria. Reviewed studies had to be published between 2005 to 2021, examine preservice teacher cognitions in ESL/EFL contexts, and represent all continents of the world. In this regard, one of the researcher's goals was to identify whether preservice teacher cognition research yielded similar/consistent findings despite the diverse educational and international contexts. At the same time, the researcher attempted to cover a wide array of cognitions related to preservice teachers' beliefs as language learners, as students in teacher education programs, and as emerging practitioners. In so doing, the researcher adopted a thematic approach in reviewing empirical preservice teacher cognition research before concluding with potential pedagogical implications for educators and teacher education programs.

\section{Literature Review}

Appendix A overviews the studies that investigated ESL and EFL preservice teacher cognitions spanning from 2005 to 2021. Refer to Appendix A (pp. 23-24) for information about the main focus and major findings of the studies reviewed in this paper. Although this review examined ESL/EFL preservice teacher cognitions spanning from 2005 to 2021, it is noteworthy that the thematic patterns we enumerate below are consistent with the thematic patterns identified by Borg (2015) when he reviewed language teacher cognition studies spanning a period from 1989 to 2004. Specially, Borg (2015) noted the following.

These studies shed light on a number of themes in the study of pre-service language teacher cognition: (a) the influence of prior language learning experience on pre-service 
teachers' cognitions; (b) pre-service teachers' beliefs about language teaching; (c) cognitions in relation to practicum experiences and (d) pre-service teachers' instructional decision-making and practical knowledge (p. 58).

\section{Preservice Teachers' Beliefs about Evaluations}

In Schoolteacher: A sociological study, Lortie (1975) argued that the in-service teachers' beliefs about teaching are influenced by their experiences as learners or what he called teachers' apprenticeship of observation. Ostensibly, teacher education and practicum are not the only factors that contribute to preservice teachers' perceptions and beliefs about teaching. On this account, referring to preservice teachers, He, Valcke, and Aelterman (2011) pointed out that "any teaching that challenges their educational beliefs would be dismissed as theoretical, unworkable, or simply wrong" (p. 1297). The authors went on to emphasize the role of preservice teachers' beliefs in shaping their every instructional move. The focus of their study was on how teachers' beliefs affect their evaluations of students' work: 'teachers' evaluations are usually done in the context of comparing worthiness, appropriateness, goodness, validity, effect, etc." (He et al., 2011, p. 1298). Thus, evaluations, even when they rely on specific criteria/rubrics, are subjective and influenced by teachers' preferences and beliefs. As the authors readily noted, when evaluating students, preservice teachers might not always be aware that their evaluations are ineluctably subjective and characterized by categorizations and value judgements. He et al. 2011 examined 56 pre-service teachers in a four-year elementary education program from three normal universities in China. There were 39 female and 17 male preservice teachers majoring in Chinese, Mathematics, Science and English. Regarding data collection, the authors used "entry and exit individual writing interviews, audiotaped group interviews, face to face interviews with 20,18 , and 18 per-service students from three universities respectively" (He et al., p. 1299). Data was analyzed according to five structural categories of evaluation: who, when, how, why and what.

As such, findings indicated that preservice teachers' beliefs about evaluation could be classified into two main categories: student centered beliefs and teacher centered beliefs. On the one hand, preservice teachers referred to their experiences as learners when they reflected on their beliefs about evaluations. To illustrate, one of the participants in the study, Yang Xiu, compared his memories of his teachers who used to mistreat students with his future teaching self, "when I was young, I often observed my classmates being reprimanded by teachers for trivial things. From then on, I promised to be a good teacher who could evaluate and praise pupils fairly" (He et al.,2011, pp. 1301-1302). On the other hand, participants in the study expressed their frustration with the notable gap between their beliefs about evaluations and what is expected from them once they start their teaching career. To bridge this gap, the study invites teacher education programs to provide comprehensive training to preservice teachers to help them conciliate their own beliefs about evaluations with the pedagogical and instructional contingencies in this regard.

\section{Preservice Teacher Cognition Development during/after Teacher Education Program}

The articles that examined preservice teacher cognition development during and after teachereducation coursework started from the premise that student teachers embark in their teacher education programs with naïve, subjective, and pedagogically inadequate understandings of teaching and learning (Brookhart \& Freeman, 1992). Other studies noted an impact of theoretical 
coursework but did not specify the precise nature of such impact. Likewise, Wong (2010) examined the beliefs of 25 Bachelor's in TESL student teachers to ascertain whether their beliefs change or remain stable over time. The findings indicated that most participants (96\%) supported the belief that learning a second language is easier for children than adults. The other two beliefs about language learning on which most participants agreed were the special abilities of certain people to learn a language (88\%) and the presence of a national origin variable to language learning (56\% of the participants thought that Malaysians were "very good" language learners).

Regarding language learning difficulty, $68 \%$ of participants believed that some languages are easier to learn than others are. At the same time, $80 \%$ of them believed that reading in a foreign language is easier than writing. In sum: Wong (2010) indicated that preservice teachers' beliefs have slightly changed when they reported on their beliefs 14 months after the study. For instance, prior to the study, $76 \%$ of participants believed that learning grammar is the most important aspect of learning a foreign language; however, 14 months later, only $60 \%$ of participants maintained the same belief. Additionally, $80 \%$ believed reading in a foreign language was easier than writing. After the study, however, this number dropped to 68\%. As you can see, while some preservice teachers' beliefs about language learning did not drastically change, Wong (2010) emphasized that these perceptions are not set in stone.

A concrete example of the impact of education coursework on ESL preservice teacher cognitions can be found in (Amory, 2020) where the author traced the learning and developmental trajectory of a female preservice teacher during her MA in TESL. Informed by a Sociocultural approach to second language teacher education, the participant's academic preparation emphasized dialogic, student-centered pedagogies that foster student engagement. While confirming previous researchers' observations about the complex, recursive, and multifaceted aspects of preservice teacher cognitions, this longitudinal study underlined the dialectic relationship between sociocultural-based teacher education preparation and preservice teacher cognition on the one hand, and the dialogic nature of preservice teacher cognition on the other hand. In other words, the ESL preservice teacher in this study immersed in a recursive process of practice and reflection. Turkish EFL teacher education offers another concrete example. Specifically, Kavanoz, Yüksel, and Varol (2017) reported that the teacher education program created an increase in preservice teachers' awareness and "an improvement in their understanding of the processes inherent to foreign language teaching and learning" (p. 119).

From another perspective, Burri (2015) examined 15 student teachers' beliefs about pronunciation pedagogy and instruction during a postgraduate course on pronunciation. Ten student teachers in the study identified as nonnative English speakers (NNESs). The researcher collected data using focus group interviews, questionnaires, observations, and interviews. These methodological choices allowed the researcher to collect reliable data on how native and NNES student teachers' cognitions developed while taking the pronunciation pedagogy course. Findings indicated that preservice teachers' cognition development is a complex process. It is notable, nonetheless, that the student teachers' cognitions (beliefs, attitudes, and knowledge) about pronunciation pedagogy have significantly developed during and after the course on pronunciation pedagogy. Let us offer a concrete example to illustrate this point. Student teachers shifted their pronunciation instruction strategy from favoring teaching individual sounds (segmentals) to a more balanced approach to pronunciation instruction that focused on the 
melody of the English language (suprasegmentals). It is also worthy of note that cognitions about pronunciation pedagogy were subject to development and transformation regardless of the student teachers' L1s (native languages). Along similar lines, NNES preservice teachers expressed an increase in awareness of their spoken English. In this respect, the collaboration between native and NNES preservice teachers played a critical role in facilitating participants' cognition growth. Thanks to collaborative teaching, the NNES student teachers improved their self-perceived pronunciation skills while the native English speaking student teachers have shown a growth in their beliefs in the NNESs potential for teaching English pronunciation.

Mattheoudakis (2007) examined preservice teachers' beliefs about EFL teaching and learning in Greece. The study included 66 participants. The researcher monitored the progress of 36 preservice teachers from their first year in the education program until the fourth year. A second group of 30 preservice teachers who chose to do their practicum participated in the study. Using self-report questionnaires, the researcher aimed at identifying changes in preservice teachers' beliefs about teaching and learning EFL during the teacher education program. Particularly, Mattheoudakis focused on the role of teaching practice on preservice teachers' beliefs. The findings suggested that preservice teachers majoring in education at the Aristotle University of Thessaloniki in Greece started the program with pre-established beliefs about English language learning and teaching. In this view, most incoming students believed in the importance of vocabulary and grammar in language learning. The study also indicated that attending an education program benefited to most participants in developing their teacher cognitions. Of equal importance, the study emphasized that cognition development and change is a gradual process. Most importantly, while the education program coursework contributed to a significant transformation in preservice teachers' cognitions about teaching and learning EFL, the study revealed that practicum had a lesser impact. In the same fashion, Gürsoy (2013) confirmed that both prior language learning experiences and teacher education coursework contributed to ELT trainees' developing cognitions about teaching and learning English.

\section{The Effects of Practicum on ESL/EFL Preservice Teacher Cognitions}

Teaching remains a highly cognitive activity where a myriad of factors-including but not limited to knowledge, learning experience, belief system, pedagogical inclinations etc.-shape preservice teachers' beliefs. From his vintage point, Borg (2003) explained this complex cognitive sphere by referring to teachers as active, thinking decision-makers who make instructional choices by drawing on complex practically oriented, personalized and contextsensitive networks of knowledge, thoughts and beliefs" (p.81). Although research that examined how practicum shapes ESL and EFL preservice teacher cognitions did not indicate an overwhelming potential for practicum in developing ESL/EFL preservice teacher cognitions, there is evidence; however, that preservice teachers are able to reflect on their pre-existing beliefs related to teaching, deconstruct some of their previous cognitions, and construct new ones. For instance, Yuan and Lee (2014) tracked Chinese EFL pre-service teachers' changing beliefs during practicum. The authors concluded that belief changes followed four processes. (1) Confirmation: some teaching practices confirmed their prior beliefs, (2) Realization involved awareness of a new belief, (3) Elaboration: consolidation of existing beliefs, and (4) Disagreement: rejecting a previously held belief. 
In Turkey, Çimen and Daloğlu (2019) concluded that their six preservice EFL teacher participants' pre-practicum cognitions were shaped by their experiences as learners and by teacher education coursework. After practicum, the EFL preservice teachers improved their classroom management strategies, but there was limited improvement in overcoming educational policy-related challenges. In like manner, Albaba (2017) noted that the student teachers in his study believed they were not prepared enough to handle classroom teaching before they started practicum. During practicum, participants had limited autonomy. Their beliefs about good teaching often conflicted with their mentors' views. After two years of full-time teaching, participants felt that the teacher education program equipped them with useful theoretical tools, but they realized that school expectations limited their autonomy. In contrast, Yüksel and Başaran (2019) found that practicum provided preservice teachers with a real-life experience allowing them to transfer some of their beliefs as learners into their teaching practice.

In the South African context, Heeralal and Bayaga (2011) described the challenges faced by South African preservice teachers during practicum. The authors noticed that most of these challenges were due to a lack of preparation and difficulties in adapting with school mentors. Another study, from China this time, underlined how EFL student teachers refer to their learning repertoires and experiences to become agentive - and in a sense selective-in the way they implement their instruction.

[Although] these 4 student teachers had shown different theoretical orientations in the protocols, they shared similar patterns of instructional practices in the Teaching Practicum. It was also found that the new teaching method practiced in the teacher education programme was re-conceptualised by these student teachers in the actual teaching context because of the strong influence of their personal agency beliefs (Tang, Lee \& Chun, 2012, p. 90).

Finally, Buss (2017) explained that undergraduate TESL students in two Canadian universities, who received explicit instruction on how to teach pronunciation, became more confident about their ability to teach the subject and cognizant of their speech limitations. Equally important is the fact that interactions between the native English speaking student teacher group and the nonnative English speaking student teacher group helped the latter in their cognitive development.

\section{Preservice Teacher Perceptions of Teachers' Knowledge and Performance}

This section reviewed two studies that examined preservice teachers' beliefs about teacherrelated aspects (elements of English teachers' knowledge base and what makes a good or bad teacher). In this context, Cárdenas and Osorio (2009) reported on five preservice teachers' beliefs about what constitutes the most fundamental elements of English teachers' knowledge base. The participants were preservice teachers in their last year of a bachelor's degree program in Foreign Languages at Universidad de La Salle, Colombia. All participants took their practicum at Academia La Salle San Benildo School where they worked with first and fifth graders. Table 1 overviews the participants' beliefs and comments about different components related to English teachers' knowledge base. 
Arab World English Journal (AWEJ) Volume 12. Number 4. December 2021

English as a Second Language and English as a Foreign Language Preservice

CHMARKH

Table 1. Summary of findings

\begin{tabular}{|c|c|c|}
\hline $\begin{array}{l}\text { Knowledge base } \\
\text { component }\end{array}$ & Participants' belief(s) & Participants' comments \\
\hline $\begin{array}{l}\text { 1. Experience } \\
\text { as learners }\end{array}$ & $\begin{array}{l}\text { Participants' experiences as learners } \\
\text { shaped their perceptions of teachers' } \\
\text { knowledge base }\end{array}$ & $\begin{array}{l}\text { Mabel: "My experiences as a student might be } \\
\text { helpful for me to understand future students of } \\
\text { mine." }\end{array}$ \\
\hline $\begin{array}{l}\text { 2. Content } \\
\text { knowledge }\end{array}$ & $\begin{array}{l}\text { Most participants described content } \\
\text { knowledge as extremely important. }\end{array}$ & $\begin{array}{l}\text { Natalia: "If you don't have language mastery, it } \\
\text { will be more difficult to have a good } \\
\text { performance." }\end{array}$ \\
\hline $\begin{array}{l}\text { 3. Knowledge } \\
\text { of students }\end{array}$ & $\begin{array}{l}\text { Knowing the students facilitates the } \\
\text { teaching task. }\end{array}$ & $\begin{array}{l}\text { Julieth: "It's important to know what the } \\
\text { students like and dislike to take the right } \\
\text { decisions when teaching." }\end{array}$ \\
\hline $\begin{array}{l}\text { 4. } \begin{array}{l}\text { Pedagogical } \\
\text { knowledge }\end{array}\end{array}$ & $\begin{array}{l}60 \% \text { of participants viewed pedagogical } \\
\text { knowledge as 'totally important' }\end{array}$ & $\begin{array}{l}\text { Yurani: "It's not enough to have content } \\
\text { knowledge, you need to know how, to whom, } \\
\text { and in which context to teach" }\end{array}$ \\
\hline
\end{tabular}

Note 1. Adopted from Cárdenas and Osorio (2009, pp. 119-125)

Fajet et al. (2005) evaluated preservice teachers' beliefs about the characteristics of good and bad teachers. Using questionnaires, surveys, and interviews, the authors examined the perceptions of 62 students enrolled in an introductory education course at the University of Miami, Florida. It was found that participants' perceptions of good teachers were classified according to themes. The most important theme was related to pedagogy and classroom management: "students believed that good teachers are creative and make learning enjoyable, fun, and interesting" (p. 721). The second most important theme was related to the personal characteristics. For example, attributes such as enthusiasm, energy, passion, motivation, patience, and honesty were viewed as important. Participants had also emphasized that good teachers build rapport with students and maintain positive attitudes toward them. Surprisingly, the least important theme according to the participants was subject matter knowledge.

Regarding poor teachers, attitudes toward students was seen as the most important theme. Participants believed that poor teachers do not care about their students (whether they learn or not). The personal characteristics theme came second: participants used adjectives like rigid, uncaring, and boring to describe poor teachers. Poor pedagogy and classroom management was the third theme. On this account, one participant explained that "bad teachers just give worksheets and lecture all the time. It's like, O.K. read chapter 11 and answer the questions." The fourth theme concerned teachers' attitudes toward the teaching profession. One participant thought poor teachers are "just doing it to get the paycheck." (p. 723). Finally, similar to the participants' perceptions of good teachers, the lack of subject matter knowledge was the least mentioned characteristic in their beliefs about poor teachers.

\section{Discussion}

As mentioned earlier, Borg (2003) delineated four major factors that contribute to the development of teacher cognitions. First, he mentioned schooling and prior experiences that 
teachers had as language learners as a source of common beliefs about teaching. Second, he described the role of professional coursework in teacher cognition: typically, coursework is provided by universities (teacher educator/education programs) and training institutes. Third, contextual factors may lead to the modification or adjustment of certain previously held beliefs. Finally, classroom practice refers to the interaction between teacher cognitions and contextual factors including the subject being taught, the students, the school setting...etc. Although the studies included in this review approached preservice teacher cognitions through different lenses and in different contexts, their analyses focused on four main issues/themes related to preservice teacher beliefs and cognitions.

(1) The effect of prior language learning experiences on pre-service teachers' cognitions,

(2) The influence of teaching practice on preservice teacher cognitions,

(3) Preservice teachers' beliefs about language teachers and teaching,

(4) The effects of teacher education coursework in shaping preservice teacher cognitions.

\section{Prior Language Learning Experiences' Effects on Preservice Teacher Cognitions}

In fact, most studies included in this review emphasized the critical role of preservice teachers' prior language learning experiences in shaping their beliefs about English language teaching. Indeed, 16 of the 23 studies reviewed in this paper explicitly mentioned that preservice teachers start their teacher education programs with a set of previously held beliefs about language teaching. While these beliefs remain malleable and subject to change/adjustment after teacher education coursework and practicum, the process of cognitive change remains lengthy and complex. That is, preservice teachers' cognitions develop in a recursive and reflective fashion. The more ESL/EFL preservice teachers are exposed to theoretical coursework and engaged in teaching practicum, the more likely they are to reflect, evaluate, and revise their beliefs about teaching and learning in ESL/EFL contexts. In other words, preservice teachers' first interactions with new theories and teaching methods would frequently be evaluated against their prior experiences as language learners. As such, preservice teachers might sometimes resist accepting a different belief if it conflicts with one of their strongly held views about teaching and learning. In this view, Simon (2009) argued that "belief change is highly complex; cognitive change does not imply behavioral change; belief change may occur as confirmation or restructuring of existing belief systems" (p.23). This constant back and forth between deconstructing prior held beliefs and - occasionally — constructing new or more elaborate ones remains a critical phase in preservice teachers academic and professional growth.

\section{The Influence of Practicum/Teaching Practice}

Most studies that included a practicum portion in their research design concluded that teaching practice contributed to some extent to the development of preservice teacher cognitions in matters related to classroom management, decision-making, collaboration with peers, content knowledge, and understanding student needs. However, it is important to note that ESL/EFL preservice teacher cognition literature emphasized the gap that exists between preservice teachers' own beliefs about English language teaching and the reality, requirements, and expectations of the school communities and especially the mentors with whom they interact during practicum. As discussed in He et al. (2011), Yuan and Lee (2014), Albaba (2017), and Mattheoudakis (2007), the tensions between preservice teachers' own beliefs and their mentors'/schools' expectations creates a feeling of frustration and demotivation among 
many student teachers. Quite often, preservice teachers lack the support and preparation they so desperately need to negotiate moments of disagreement, tension, and conflict that might occur during their field placement. Conflictual beliefs could also arise between preservice teachers' experiences as learners and their emerging identities as teachers. To illustrate, Borg explained in an interview with Birello that it is normal for preservice teachers to encounter tension when confronting two conflicting beliefs. Borg elaborated by asserting that:

There are teachers who say it is important to get learners to discover grammar for themselves, but it is also important for me to cover the curriculum quickly so there is a tension there between a belief in the need for efficiency and another belief (Birello, 2012, p. 91).

Central to all of this is the role of teacher education programs in creating channels that help mediate such conflicts and facilitate ESL/EFL student teachers' experience in conciliating their prior beliefs with the novel ones encountered in practicum. While mentors supervising student teachers in public schools have more experience and pedagogical knowledge, it is critical to allow student teachers to voice their opinions and practice different instructional approaches. In this sense, teacher education programs and school mentors should act as facilitators rather than authority figures by allowing student teachers to be creative and agentive during their field placement.

\section{ESL/EFL Pre-Service Teachers' Beliefs about Teachers and Teaching}

- Borg (2003) illustrated the difficulties that preservice teachers encounter when trying to visualize and predict their future teaching selves. He refers to preservice teachers' "day-to-day outlook on their careers, and "very few (...) dared to visualize, with confidence and clarity what their in-service experience might be like" (p. 64). Interestingly, the studies reviewed in this paper emphasized the role of ESL/EFL preservice teachers' beliefs that date back to their language learning experiences in shaping their first conceptualizations of English language teaching and teachers. For instance, relying largely on their experiences as language learners, most participants in Cárdenas and Osorio (2009) outlined the sets of knowledge base components and teaching-related practices that teachers should possess. They especially highlighted the influence of their experiences as learners in facilitating their understanding of students' needs. Teacher cognitions are dynamic and reflect a constant back and forth between reflection and practice. While the teacher education coursework offers student teachers the opportunity to reflect on their practice, practicum rarely provides students teachers with such opportunities to be reflective practitioners. As discussed earlier, there is a need to bridge the gap between the entirely theoretical nature of the teacher education coursework and the practice-oriented nature of practicum. Of great significance here is the role of university supervisors-who are typically doctoral students in education - as mediators to help bridge the gap and the disconnect between teacher education programs and schools/mentors. In the same fashion, preservice teachers refer to their prior cognitions when interacting with their mentors and when evaluating/reflecting on other teachers. It is important to note, moreover, that the more distant preservice teachers' beliefs are from their mentors, the more tension and frustration preservice teachers tend to encounter. Likewise, preservice teachers' portrayals of good and bad teachers in Fajet et al. (2005) were largely informed by their own experiences as language learners. 


\section{The Effect of Teacher Education in Shaping ESL/EFL Pre-Service Teachers' Cognitions}

ESL/EFL preservice teachers often start their teaching education coursework with a naïve understanding of teaching and learning. However, it is important to note that the studies reviewed in this paper revealed a significant effect of teacher education coursework and academic preparation on developing preservice teachers' cognitions (Albaba, 2017; Amory; 2020, Burri, 2015; Buss, 2017; Çimen \& Daloğlu, 2019; Da Silva, 2005; Guerrettaz et al., 2020; Šipošová, 2021; Tang, Lee \& Chun, 2012; Wong, 2010). Of great significance here is what AlBaba (2017) revealed regarding the long-term impact of teacher education coursework on EFL preservice teachers. To illustrate, when his participants were interviewed two years after starting their full-time teaching jobs, they explained that teacher education coursework equipped them with an adequate theoretical foundation in teaching and learning EFL. Accordingly, we can argue that teacher education programs might potentially offer effective and safe transition venues where ESL/EFL preservice teachers are encouraged and trained to negotiate their past and current/learned beliefs before embarking in practicum where contextual factors are more contingent and stressful.

There is, however, a need to provide adequate and individualized support to ESL/EFL student teachers to help them develop their language educator identity. Although the theoretical coursework is invaluable in this regard, it remains just one piece of the puzzle. ESL/EFL preservice teachers often feel overwhelmed by the discrepancies between theory and practice. That is, what they learn in their teacher education coursework may not always translate to better practice during practicum. Contextual factors need to be considered to better assist every ESL/EFL student teacher navigate and negotiate their field placement. In simple terms, each classroom, school, mentor, and student teacher is different. Taking these individual/contextual differences into account would maximize the chances of ESL/EFL student teachers to thrive during practicum.

\section{Implications}

This section set forth to explore how ESL/EFL preservice teachers' cognitions may contribute to the understanding and perhaps examination of in-service teaching practice. At the same time, challenges that could prevent connections and correlations between preservice teacher cognitions and in-service teacher experiences will be discussed. It is also relevant to underscore the complex and abstract aspects of teacher cognitions and beliefs. The first implication relates to the role of ESL/EFL preservice teacher cognitions, experiences, and beliefs as language learners in shaping their future teaching selves. The reviewed literature indicated that preservice teachers rely on their beliefs as language learners when negotiating different or newer beliefs either in their coursework or practicum. In like manner, preservice teachers' performance as learners and their perceptions of the good and bad teachers they had as language learners appear to be decisive factors in shaping their future teaching practice. In other words, it is possible that inservice teachers reproduce teaching methods that combine what they perceived as good instructional practices from their own repertoires as language learners and from the teachers they considered to be role models as far as effective instruction is concerned.

Seen in this light, teacher education programs could play a significant role in supporting their student teacher candidates by identifying their beliefs about teaching and learning early on in the program. In so doing, teacher education programs could create an inclusive academic preparation 
that builds on student teachers' own perceptions toward the consolidation and development of familiar as well as newer beliefs about teaching and learning. What is evident here is that learners' schemata hold valuable predictors of future teaching performance. With that in mind, longitudinal studies that focus on teachers' experiences as language learners, student teachers, and in-service teachers have the potential of revealing if such correlations exist. The challenge as Burns et al. (2015) pointed out remains in substantiating and making sense of teachers' complex thought systems. In this sense, the authors argued that the challenge "is how to think beyond our current empirical structures and categories to capture this mental work. To paraphrase Yeats's observation, we may no longer be able to separate the dancer from the dance" (p. 597). To put it otherwise, teacher cognitions may sometimes be impenetrable, yet they are inseparable from their owners' teaching practice. Alternatively, exploring how preservice teachers' experiences as language learners influence their cognitions can be approached differently in a way that would not necessarily require a longitudinal study. That is, teaching expertise research could examine the type of learner and preservice teacher beliefs and experiences that certain designated expert teachers had. Of great significance here is the potential for uncovering if expert teachers take similar routes in their journey toward expertise and success in teaching. The challenge remains, however, in establishing reliable criteria for selecting expert teacher participants and coming up with a concrete definition of successful/effective teaching.

The findings also support the idea that a combination of theoretical coursework and practicum would contribute to the consolidation of preservice teachers' existing beliefs and the reevaluation of emerging beliefs. It would make sense, therefore, if teacher education programs train student teachers to deal with teaching-related practices by providing theory and practice informed training. Central to all of this is the opportunity that such preparation could offer in terms of helping ESL/EFL preservice teachers negotiate and conciliate what is often viewed as a set of conflicting beliefs. More specifically, if teacher education programs can provide this type of mentoring and support, preservice teachers would be better prepared for their field placements where they will inevitably encounter some tension; one that arises from the interaction between their own views on teaching and those of their schools and mentors.

Of equal importance, ESL/EFL preservice teachers should remain open and receptive to new ideas and be able to revise/reevaluate their conceptions if necessary. By helping ESL/EFL student teachers negotiate these experiences, teacher education programs would maximize the chances of their student teachers to have productive teaching experiences in their field placements and later in their teaching careers. That is, the more constructive and diverse teaching and learning experiences that ESL/EFL preservice teachers are exposed to, the more sophisticated knowledge schemata they would be able to develop. In this view, Tsui (2003) considered rich knowledge schemata to be a key attribute of expert teachers. While theoretical coursework is necessary, ESL/EFL preservice teachers would learn best about teaching by teaching. The more they teach, the more experiences they can add to their repertoires and knowledge schemata.

Lastly, the context and quality of the practicum or field placement experiences remain critical. For instance, the mentor teacher, the school culture, and the quality of feedback preservice teachers receive remain integral parts of their personal and professional development. As such, a good student teacher may not thrive in practicum if they are placed with an inflexible or 
inexperienced mentor. Conversely, an average student teacher may exceed their performance potential if paired with an experienced and supportive mentor. Of equal importance is the quality of the feedback that student teachers receive from their mentors during practicum. In this view, by directing student teachers' attention to reasonable areas of improvement/focus, highlighting their strengths before their weaknesses, and respecting their views, mentors would pave the path of their ESL/EFL student teachers toward a successful teaching career.

\section{Conclusion}

This paper sought to examine empirical ESL/EFL preservice teacher cognition research published between 2005 to date. The main objective was to explore the nature and development of preservice ESL and EFL teacher cognitions as they relate to their education coursework and teaching practice. As this review has shown, preservice teacher cognitions are complex, multifaceted, recursive, sometimes impenetrable, and usually related to preservice teachers' own experiences as language learners. Interestingly, although studies included in this review have been conducted in different instructional, educational, and international contexts, the findings have been consistent. Broadly speaking, preservice teachers' experiences as learners and their actual potential as student teachers and future educators aside, the literature has also emphasized the critical role of teacher education programs in the academic preparation and professional development of preservice teachers. Accordingly, the reviewed literature invites teacher education programs to provide a solid, supportive, and comprehensive ESL/EFL preserviceteacher preparation that accounts for three indispensable factors. (1). Valuing and building on preservice teachers' beliefs as English language learners, (2). facilitating preservice teachers' negotiation of newer beliefs resulting from teacher education coursework, and (3). preparing preservice teachers to negotiate tensions resulting from conflictual beliefs between them and their mentors. Clearly, it is critical for student teachers to have a solid academic foundation that values their beliefs and help them construct and implement newer ones without being alienated. In sum, this review of preservice ESL/EFL teacher cognition research has shown that having a successful teacher education experience is a stepping-stone toward a successful teaching career.

About the Author. Mustapha Chmarkh is a doctoral candidate in Foreign, Second, and Multilingual Education at the Ohio State University, USA. He is currently working on his doctoral dissertation on counter argumentation in ESL Composition. His research interests include argumentation in ESL, dialogic instruction, scaffolding language learning, and ESL writers and the writing center. ORCID. https://orcid.org/0000-0001-9294-4364

\section{References}

Amory, M. D. (2020). Teach off your students: A longitudinal analysis of an ESL pre-service teacher's twisting process of conceptual development. The European Journal of Applied Linguistics and TEFL, 9(2), 105-129.

Birello, M. (2012). Teacher cognition and language teacher education: Beliefs and practice. A conversation with Simon Borg. Bellaterra Journal of Teaching \& Learning Language \& Literature, 5(2), 88-94. Available at https://www.raco.cat/index.php/Bellaterra/article /view/253372

Borg, S. (2003). Teacher cognition in language teaching: A review of research on what language teachers think, know, believe, and do. Language Teaching, 36(2), 81-109. DOI: https://doi.org/10.1017/S0261444803001903 
Borg, S. (2015). Teacher cognition and language education: Research and practice. Bloomsbury Publishing.

Brookhart, S., \& Freeman, D. (1992). Characteristics of entering teacher candidates. Review of Educational Research, 62(1), 37-60. Available at http://www.jstor.org/stable/1170715

Bulut Albaba, M. (2017). Teacher learning during transition from pre-service to novice EFL teacher: A longitudinal case study. Novitas-ROYAL: Research on Youth and Language, 11(2), 142- 154.

Burns, A., Freeman D., \& Edwards, E. (2015). Theorizing and studying the language-teaching mind: Mapping research on language teacher cognition. Modern Language Journal, 99(3), 85-601. https://doi.org/10.1111/modl.12245

Burri, M. (2015). Student teachers' cognition about L2 pronunciation instruction: A case study. Australian Journal of Teacher Education, 40(10), 66-87. http://dx.doi.org/10.14221/ajte. $\underline{2015 \mathrm{v} 40 \mathrm{n} 10.5}$

Buss, L. (2017). The role of training in shaping teacher cognition related to L2 pronunciation. Ilha do Desterro a Journal of English Language, Literatures in English and Cultural Studies, 70(3), 201-226. DOI: 10.5007/2175-8026.2017v70n3p201

Cárdenas, A., \& Suárez Osorio, J. M. (2009). Pre-service teachers' knowledge base at La Salle University. HOW Journal, 16(1), 113-130.

Cheung, A., \& Hennebry-Leung, M. (2020). Exploring an ESL teachers' beliefs and practices of teaching literary texts: A case study in Hong Kong. Language Teaching Research, 1-26. https://doi.org/10.1177/1362168820933447

Çimen, S. \& Daloğlu, A. (2019). Dealing with in-class challenges: Pre-service teacher cognitions and influences. Journal of Language and Linguistic Studies, 15(3), 754-772. doi: 10.172 63/jlls.631499

Cognition [Def. 1]. (2019). In Oxford Lexico Dictionary Online. https://www.lexico.com/en/definit ion/cognition

Davies, S. F. (2019). French EFL teacher cognition of the intercultural dimension of their teaching. (Unpublished Doctoral dissertation). Alliant International University, San Diego.

Da Silva, M. (2005). Constructing the teaching process from inside out: How Pre-service teachers make sense of their perceptions of the teaching of the four skills. TESL-EJ, 9(2), 1-19. https://eric.ed.gov/?id=EJ1065833

Fajet, W., Bello, M., Leftwich, S.A., Mesler, J., \& Shaver, A. (2005). Pre-service teachers' perceptions in beginning education classes. Teaching and Teacher Education, 21(6), 717727. https://doi.org/10.1016/j.tate.2005.05.002

Guerrettaz, A. M., Zahler, T., Sotirovska, V., \& Boyd, A. S. (2020). 'We acted like ELLs': A pedagogy of embodiment in preservice teacher education. Language Teaching Research, 1-25. https://doi.org/10.1177/1362168820909980

Gürsoy, E. (2013). What is effective in forming our beliefs: Experience or education? Procedia $\begin{array}{lllll}\text { Social and Behavioral } & \text { Sciences, } & 70, & \text { 763-770. }\end{array}$ https://doi.org/10.1016/j.sbspro.2013.01.121

He, Q., Valcke, M., \& Aelterman, A. (2011). Pre-service teachers' beliefs about evaluation. Procedia Social and Behavioral Sciences, 29, 1296-1304. Available at https://www.sciencedirect.com /science/article/pii/S1877042811028278?via\%3Dihub 
Heeralal, P., \& Bayaga, A. (2011). Pre-service teachers' experiences of teaching practice: Case of South African University. Journal of the Social Sciences, 28(2), 99-105. https://doi.org/10. 1080/09718923.2011.11892933

Kavanoz, S., Yüksel, G. H., \& Varol, B. (2017). Evolvement of pre-service language teachers' beliefs through teacher education. International Journal of Progressive Education, 13(1), $119-135$.

Lim, S. (2016). Learning to teach intelligible pronunciation for ASEAN English as a Lingua Franca: A sociocultural investigation of Cambodian pre-service teacher cognition and practice. RELC Journal, 47(3), 313-329. https://doi.org/10.1177/0033688216631176

Lortie, D. (1975). Schoolteacher: A sociological study. University of Chicago Press.

Macalister, J. (2012). Pre-service teacher cognition and vocabulary teaching. RELC Journal, 43(1) 99-111. https://doi.org/10.1177/0033688212439312

Mattheoudakis, M. (2007). Tracking changes in pre-service EFL teacher beliefs in Greece: A longitudinal study. Teaching and Teacher Education, 23(8), 1272-1288. https://doi.org/10. 1016/j.tate.2006.06.001

Simon, P. (2009) The relationship between teacher education, teacher cognition and classroom practice in language teaching: A case study of MA students' beliefs about grammar teaching (unpublished Doctoral dissertation). University of Leeds, United Kingdom.

Šipošová, M. (2021). Pre-service teachers' beliefs about effective English language teaching and learning in Slovak educational context. Philologia 31(1): 21-45

Tang, E., Lee, J., \& Chun, C. (2012). Development of teaching beliefs and the focus of change in the process of pre-service ESL teacher education. Australian Journal of Teacher Education, 37(5), 90-107. https://doi.org/10.14221/ajte.2012v37n5.8

Tsui, A. (2003). Understanding expertise in teaching: Case studies of second language teachers. Cambridge, U.K: Cambridge University Press.

Woods, D. (1996). Teacher cognition in language teaching: Beliefs, decision-making, and classroom practice. Cambridge University Press.

Wong, M.S. (2010). Beliefs about language learning: A study of Malaysian pre-service teachers. The RELC Journal, 41(2), 123-136. https://doi.org/10.1177/0033688210373124

Yuan, R., \& Lee, I. (2014). Pre-service teachers' changing beliefs in the teaching practicum: Three cases in an EFL context. System, 44, 1-12. https://doi.org/10.1016/j.system.2014.02.002

Yüksel, L., \& Başaran, B. C. (2019). The change in ELT pre-service teachers' cognition during teaching practicum. Journal of Education and Training Studies, 7(10), 58-66. DOI: https: //doi.org/10.11114/jets.v7i10.4425

\section{Appendices}

Appendix A: Reviewed Studies, Their Focus, and Major Findings

\begin{tabular}{|l|l|l|}
\hline Article & Focus & Major Findings \\
\hline Buss (2017) & $\begin{array}{l}\text { ESL preservice teacher } \\
\text { cognitions regarding } \\
\text { teaching pronunciation }\end{array}$ & $\begin{array}{l}\text { “Training that combines an introduction to English } \\
\text { phonology and pronunciation teaching has a positive } \\
\text { impact on preservice teachers' cognitions" (p. 218). }\end{array}$ \\
\hline
\end{tabular}




\begin{tabular}{|c|c|c|}
\hline $\begin{array}{l}\mathrm{He} \text { et al. } \\
(2011)\end{array}$ & $\begin{array}{l}\text { Beliefs } \\
\text { evaluations }\end{array}$ & $\begin{array}{l}\text { Pre-service teachers held teacher-centered or a } \\
\text { student-centered belief about evaluation. The latter } \\
\text { was mostly influenced by their own stories as } \\
\text { language learners. }\end{array}$ \\
\hline $\begin{array}{l}\text { Yuan and Lee } \\
\text { (2014) }\end{array}$ & $\begin{array}{l}\text { Beliefs before, during, } \\
\text { and after practicum }\end{array}$ & $\begin{array}{l}\text { "Prior beliefs interacted with the new input and } \\
\text { experiences through participation, practice, and } \\
\text { reflection (...) beliefs about language teaching and } \\
\text { self-understanding as language teachers were both } \\
\text { transformed and developed" (p. 10.). }\end{array}$ \\
\hline Amory (2020) & $\begin{array}{l}\text { The conceptual } \\
\text { development of an ESL } \\
\text { preservice teacher }\end{array}$ & $\begin{array}{l}\text { The process by which preservice teachers } \\
\text { "conceptualize and enact their teaching is complex } \\
\text { and multifaceted" (p. 123). }\end{array}$ \\
\hline $\begin{array}{l}\text { Guerrettaz et } \\
\text { al. }(2020)\end{array}$ & $\begin{array}{l}\text { A pedagogy } \\
\text { embodiment in } \\
\text { education }\end{array}$ & $\begin{array}{l}\text { This pedagogy "fostered teacher-learners' } \\
\text { development of language pedagogy concept learning } \\
\text { and increased their empathy for ELLs" (p. 21). }\end{array}$ \\
\hline $\begin{array}{ll}\text { Da } & \text { Silva } \\
(2005) & \end{array}$ & $\begin{array}{l}\text { Preservice teachers' } \\
\text { perceptions of teaching } \\
\text { language skills }\end{array}$ & $\begin{array}{l}\text { Preservice teachers deconstruct their previous } \\
\text { perceptions and construct new ones informed by } \\
\text { theoretical coursework. }\end{array}$ \\
\hline $\begin{array}{l}\text { Macalister } \\
(2012)\end{array}$ & $\begin{array}{l}\text { Malaysian pre-service } \\
\text { teachers' beliefs on } \\
\text { vocabulary teaching }\end{array}$ & $\begin{array}{l}\text { Preservice teacher's beliefs and perceptions about } \\
\text { teaching vocabulary were different to some extent } \\
\text { with their trainers. }\end{array}$ \\
\hline Wong (2010) & $\begin{array}{l}\text { Beliefs on learning } \\
\text { English }\end{array}$ & $\begin{array}{l}\text { Preservice teachers' beliefs about teaching the five } \\
\text { language learning areas are dynamic and situational. }\end{array}$ \\
\hline Albaba (2017) & $\begin{array}{l}\text { Learning } \\
\text { participation in school } \\
\text { communities. }\end{array}$ & $\begin{array}{l}\text { "[When] school practices conflict with teacher's } \\
\text { educational ideals, student teacher participation in } \\
\text { the school community may foster adaptation towards } \\
\text { school practices" (p. 152). }\end{array}$ \\
\hline $\begin{array}{l}\text { Çimen and } \\
\text { Daloğlu } \\
\text { (2019) }\end{array}$ & $\begin{array}{ll}\text { Challenges } & \text { in the } \\
\text { foreign } & \text { language } \\
\text { classroom } & \end{array}$ & $\begin{array}{l}\text { "Courses in teacher education program, pre-service } \\
\text { teachers' own learning experiences, and practicum } \\
\text { experiences emerged as influences that shape their } \\
\text { cognitions" (p. 754). }\end{array}$ \\
\hline $\begin{array}{l}\text { Fajet et al. } \\
(2005)\end{array}$ & $\begin{array}{l}\text { Education students' } \\
\text { perceptions of good vs } \\
\text { poor teachers }\end{array}$ & $\begin{array}{l}\text { Teaching involves affective, interpersonal } \\
\text { relationships rather than requiring a knowledgeable } \\
\text { practitioner }\end{array}$ \\
\hline $\operatorname{Lim}(2016)$ & $\begin{array}{lr}\text { Preservice } & \text { teachers' } \\
\text { perceptions } & \text { of } \\
\text { pronunciation } & \\
\text { instruction } & \\
\end{array}$ & $\begin{array}{l}\text { Participants showed tension regarding introducing } \\
\text { the NNES pronunciation language model to their } \\
\text { students }\end{array}$ \\
\hline
\end{tabular}




\begin{tabular}{|c|c|c|}
\hline $\begin{array}{l}\text { Cheung and } \\
\text { Hennebry- } \\
\text { Leung (2020) }\end{array}$ & $\begin{array}{l}\text { Hong Kong ESL } \\
\text { teachers' beliefs about } \\
\text { teaching literary texts }\end{array}$ & $\begin{array}{l}\text { Teacher cognitions are dynamic and reflect a back } \\
\text { and forth between reflection and practice. }\end{array}$ \\
\hline Burri (2015) & $\begin{array}{l}\text { Cognition development } \\
\text { during a pronunciation } \\
\text { pedagogy course }\end{array}$ & $\begin{array}{l}\text { Participants changed some of their cognition and } \\
\text { teaching practices after taking the pronunciation } \\
\text { pedagogy course. }\end{array}$ \\
\hline $\begin{array}{l}\text { Mattheoudakis } \\
\text { (2007) }\end{array}$ & $\begin{array}{l}\text { EFL teachers' beliefs } \\
\text { about teaching and } \\
\text { learning }\end{array}$ & $\begin{array}{l}\text { After preservice teachers start their careers, their } \\
\text { practice does not contribute much to the } \\
\text { development of their beliefs. }\end{array}$ \\
\hline $\begin{array}{l}\text { Cárdenas and } \\
\text { Osorio (2009) }\end{array}$ & $\begin{array}{l}\begin{array}{l}\text { Essential } \\
\text { teachers' } \\
\text { base }\end{array} \\
\text { knowledge }\end{array}$ & $\begin{array}{l}\text { Components of teacher knowledge base are "1) } \\
\text { language knowledge 2) knowledge of students 3) } \\
\text { pedagogical knowledge 4) and the teacher's } \\
\text { personality" (p. 129). }\end{array}$ \\
\hline Davies (2019) & $\begin{array}{l}\text { The intercultural } \\
\text { dimension of French } \\
\text { EFL teacher cognitions }\end{array}$ & $\begin{array}{l}\text { There is a persistent gap between EFL policy and } \\
\text { curricula design - in intercultural teaching and } \\
\text { learning objectives - and classroom implementation }\end{array}$ \\
\hline $\begin{array}{l}\text { Yüksel and } \\
\text { Başaran } \\
\text { (2019) }\end{array}$ & $\begin{array}{l}\text { Changes in preservice } \\
\text { teacher cognitions } \\
\text { during practicum }\end{array}$ & $\begin{array}{l}\text { The practicum provides a real-life experience to } \\
\text { transform preservice teachers' beliefs as learners to } \\
\text { their teaching. }\end{array}$ \\
\hline $\begin{array}{l}\text { Heeralal and } \\
\text { Bayaga (2011) }\end{array}$ & $\begin{array}{l}\text { Challenges } \\
\text { practicum }\end{array}$ & $\begin{array}{l}\text { Pre-service teachers need to consider flexibility in } \\
\text { "1) time of course participation, 2) in content in the } \\
\text { course, 3) in instructional approaches and learning } \\
\text { materials, and 4) flexibility in course delivery and } \\
\text { logistics" (p. 99). }\end{array}$ \\
\hline $\begin{array}{l}\text { Šipošová } \\
\text { (2021) }\end{array}$ & $\begin{array}{l}\text { Slovak EFL preservice } \\
\text { teachers' beliefs about } \\
\text { effective English } \\
\text { teaching and learning }\end{array}$ & $\begin{array}{l}\text { The author emphasizes the need for education } \\
\text { programs to focus more on ELT informed teacher } \\
\text { training practices }\end{array}$ \\
\hline $\begin{array}{lr}\text { Tang, } & \text { Lee, } \\
\text { and } & \text { Chun } \\
(2012) & \end{array}$ & $\begin{array}{l}\text { Development of } \\
\text { teaching beliefs in the } \\
\text { process of pre-service } \\
\text { ESL teacher education }\end{array}$ & $\begin{array}{l}\text { Despite the standardized theoretical coursework, } \\
\text { student teachers tend to be more agentive in the way } \\
\text { their own teaching. }\end{array}$ \\
\hline Gürsoy (2013) & $\begin{array}{l}\text { What is effective in } \\
\text { forming our beliefs: } \\
\text { Experience } \\
\text { education? }\end{array}$ & $\begin{array}{l}\text { Both prior learning experiences and education play a } \\
\text { critical role in ELT trainees' developing cognitions } \\
\text { about teaching and learning English. }\end{array}$ \\
\hline $\begin{array}{l}\text { Kavanoz, } \\
\text { Yüksel, and } \\
\text { Varol (2017) }\end{array}$ & $\begin{array}{l}\text { Evolvement of pre- } \\
\text { service language } \\
\text { teachers' beliefs through } \\
\text { teacher education }\end{array}$ & $\begin{array}{l}\text { Teacher education coursework helped Turkish EFL } \\
\text { preservice teachers improve their awareness of the } \\
\text { complex processes involved in foreign language } \\
\text { teaching }\end{array}$ \\
\hline
\end{tabular}

